\title{
EEF1A2 wt Allele
}

National Cancer Institute

\section{Source}

National Cancer Institute. EEF1A2 wt Allele. NCI Thesaurus. Code C53130.

Human EEF1A2 wild-type allele is located in the vicinity of 20q13.3 and is approximately $11 \mathrm{~kb}$ in length. This allele, which encodes elongation factor 1 -alpha 2 protein, is involved in the promotion of protein elongation. The gene is expressed aberrantly at elevated levels in many ovarian cancers. 